\title{
Developing Interactive Mobile Mathematics Inquiry to Enhance Students' Mathematics Problem-solving Skill
}

\author{
https://doi.org/10.3991/ijim.v15i01.20067 \\ Moch. Bahak Udin By Arifin $(\varpi)$ \\ Universitas Muhammadiyah Sidoarjo, Sidoarjo, Indonesia \\ bahak.udin@umsida.ac.id \\ Makherus Sholeh \\ Universitas Islam Negeri Antasari Banjarmasin, Banjarmasin, Indonesia \\ Abdul Hafiz \\ Universitas Islam Kalimantan Muhammad Arsyad Al \\ Banjari, Banjarmasin, Indonesia \\ Ririn Dwi Agustin \\ IKIP Budi Utomo, Malang, Indonesia \\ Mahardika Darmawan Kusuma Wardana \\ Universitas Muhammadiyah Sidoarjo, Sidoarjo, Indonesia
}

\begin{abstract}
This research aimed to develop interactive multimedia based on scientific inquiry to improve student mathematics problem-solving as a provision for the era of Society 5.0. The research method used is the Agile Method, a software development method. One hundred twenty students of Madrasah Ibtidaiyah Teacher Education Department, Universitas Muhammadiyah Sidoarjo were involved in this research. The results of the development of Interactive Mobile Mathematics Inquiry (IMMI) were valid and proven to improve student problemsolving abilities. In particular, this increase is significant in planning and implementing student plans for a problem. The significance is due to the training in the inquiry aspects during the use of IMMI. This educational technology research implies that IMMI can be a preliminary study and a pioneer for lecturers, experts, and practitioners. Thus, IMMI can be developed further to improve students' mathematical problem-solving skills in higher education as preparation for media availability following the values of technological advances in the Society 5.0 era.
\end{abstract}

Keywords-Interactive mobile, mathematics problem solving, Society 5.0 era

\section{Introduction}

Many countries are preparing for the development and use of technology in the Society 5.0 era, which demands synergy between humans and technology. This synergy 
is expected to create new values and solve social problems through advanced technologies [1]. Previous studies showed that the use of technology in the concept of Society 5.0 has a positive impact. Research on the laboratory prototype based on Society 5.0 produced social policy decisions closer to real community responses [2]. Society 5.0 based Japanese blogs can make searching for false terms and meanings in Buddhist vocabulary more effective [3]. The development of robots with Society 5.0 values results in more functions that are useful for a company's performance [4], [5].

In higher education, the need for learning that leads to the Society 5.0 era is the development and use of technology in Interactive Mobile applications [1], [6]. This is because Interactive Mobile provides interaction between lecturers, students, and technology [7] and features that can be used easily in everyday life [8], [9], [10].

Concerning mathematics courses, there is no Interactive Mobile that can construct student knowledge through the involvement of problems in everyday life. This involvement can be generated through the principle of "inquiry" in learning [11], which can be the platform of students' performance in conducting research and logical principles [12]. Inquiry provides students learning activities in selecting, controlling variables, planning operations, and interpreting evidence [13]. When learning activities through inquiry are carried out, students become more active in seeking knowledge independently rather than recorders from the educators. An educator only acts as a facilitator and mediator [14]. Students' activity performance in inquiry learning can be increased by utilizing Interactive Mobile, which involves scientific elements that demand proof and scientific fact-finding [15]. Thus, in improving students' mathematics performance in higher education, Interactive Mobile is needed by involving the inquiry principle to enhance their mathematics performance.

Previous findings showed that Mathematics is still a difficult subject for students at the higher education higher education due to mathematics low performance in problemsolving abilities [16], [17]. In this sense, problem-solving for students means finding the result of a mathematical question and facing new conditions, and finding flexible, effective, and elegant solutions to those conditions [18], [19]. Therefore, the ability to solve mathematical problems in preparation for the Society 5.0 era requires Interactive Mobile development. It involves inquiry aspects to be more active in constructing knowledge and solving mathematical problems independently and logically. In this research, the development of Interactive Mobile is called Interactive Mobile Mathematics Inquiry (IMMI).

\section{Methodology}

\section{$2.1 \quad$ Research methods}

The IMMI development was adopted from the Agile Development Methods development steps, a group of software development methodologies based on iterative development. The requirements and solutions for this method develop through collaboration among self-governing cross-functional teams [20]. Agile method development steps include planning, development, wrapping, review, adjustment, and closure. The 
Interactive Mobile Mathematics Inquiry development steps using the agile method is shown in Figure 1.

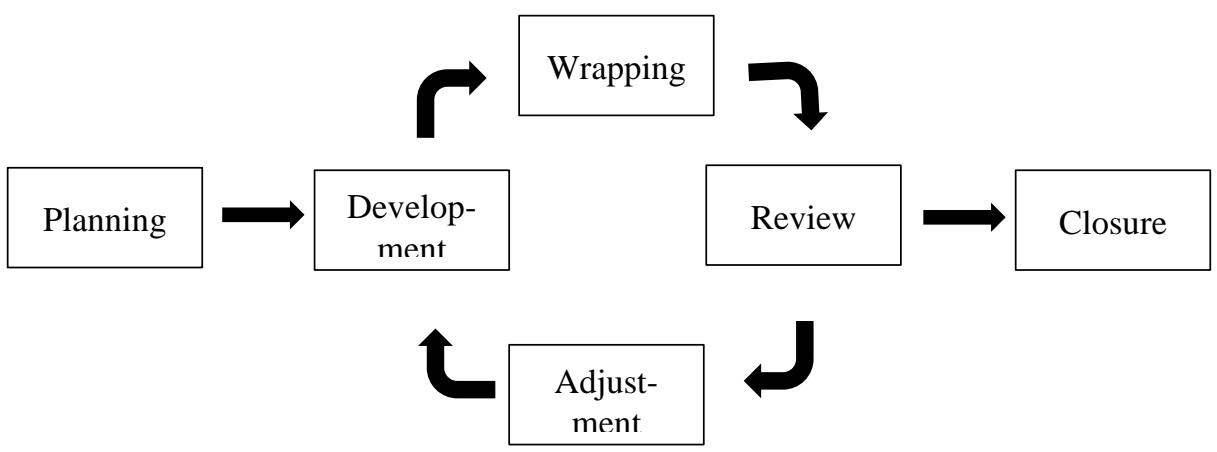

Fig. 1. IMMI Development Process

IMMI's development process involved planning, development, wrapping, review, adjustment, and closure. In the planning stage, new releases are made based on the backlog (list of activities to be worked on) along with estimated schedules and costs. This process was followed by the conceptualization and analysis of the aspects of inquiry in mobile interactive. If the existing system is being upgraded, this phase consists only of a limited analysis of the backlog items' design to be implemented. This phase included the modification of system architecture and high-higher education design. The development phase defines the changes needed to implement the backlog requirements into the package, open the package, conduct domain analysis, design, and develop mobile interactive by involving aspects of inquiry, implementing, testing, and documenting changes. The development stage consists of a micro process of discovery, discovery, and implementation. Wrapping steps included closing packages, creating an executable version of the changes, and implementing the backlog requirements. In the review step, all teams meet to present work, review progress, raise and solve problems, and add new backlog items. Risks are reviewed, and responses are determined. Step adjustments consolidate the information gathered from the review meeting into affected packages, including a different look and feel and new properties. At the closure stage, the management team felt that the variables of time, competition, requirements, cost, and quality were appropriate for the new release to occur. They declared the release "closed." This phase prepares IMMI products that are developed for general release. Integration, system testing, user documentation, preparation of training materials, and preparation of marketing materials are some of the tasks that are in the closing step. [21].

\subsection{Participants}

This study involved 120 students from the first, second, and third-year at the Department of Madrasah Ibtidaiyah Teacher Education at Universitas Muhammadiyah Sidoarjo who were programming mathematics-related subjects. Participants consisted of 
65 male and 55 female students who were determined using proportionate stratified random sampling, randomly assigning the sample by giving all students an equal opportunity to be the sample [22].

\subsection{Data collection instrument and data analysis}

The instruments used were the validation sheet for the IMMI media and the Mathematical Problem Solving (TMPS) test. The IMMI validation sheet consists of three aspects of assessment: relevance to the material, ease of use, and practicality. The IMMI validation sheet was filled in by four experts in educational technology and mathematics education. Meanwhile, TMPS consists of 20 questions in the form of math essays on the discussion of planes. These questions were divided into five questions for each task. TMPS is made by referring to indicators of solving steps according to Polya, namely in terms of understanding problems, planning solutions, implementing solution plans, and re-checking solutions [23]. This test was given to fifty students in the Department of Primary School Teacher Education at UIN Sumatera Utara. The test results showed the validity value by calculating the product-moment correlation of 0.023 and the reliability value by calculating the Cronbach alpha of 0.011 . Referring to a sig value of less than 0.05, the TMPS was considered valid and reliable [24].

Data were analyzed using simple linear regression to measure the effect of IMMI on students' mathematical problem-solving abilities. To ensure the coefficient's significance, the researcher conducted a hypothesis test by comparing the significance value with a probability of 0.05 or comparing the t-count value with the t-table, which is 1.97993 [24].

\section{Results and Discussion}

\subsection{Planning stage}

Agile planning is a project planning method that estimates work using independent work units called iterations or sprints [25]. A sprint is a team activity that focuses on a small set of work items and aims to complete them over 1-3 weeks. Agile planning determines which items to complete in each sprint and creates an iterative process to help teams learn how much they can accomplish. In this sprint process, IMMI is designed to involve aspects of the inquiry learning step as below.

- Orientation is the stage of formulating a problem; The abilities required are (a) awareness of the problem; (b) see the importance of the problem, and (c) formulate the problem.

- The conceptualization stage includes the development of a hypothesis. The abilities required in developing this hypothesis are (a) testing and classifying the data; (b) see and formulate the existing relationships logically, and formulate a hypothesis.

- The conclusion stage requires the ability to (a) look for patterns and meaning of relationships and (b) formulate conclusions

- Discussion includes the process of drawing conclusions and generalization. 
Paper-Developing Interactive Mobile Mathematics Inquiry to Enhance Students' Mathematics...

The construction of inquiry aspects in IMMI is shown in Table 1.

Table 1. Inquiry Construction in IMMI

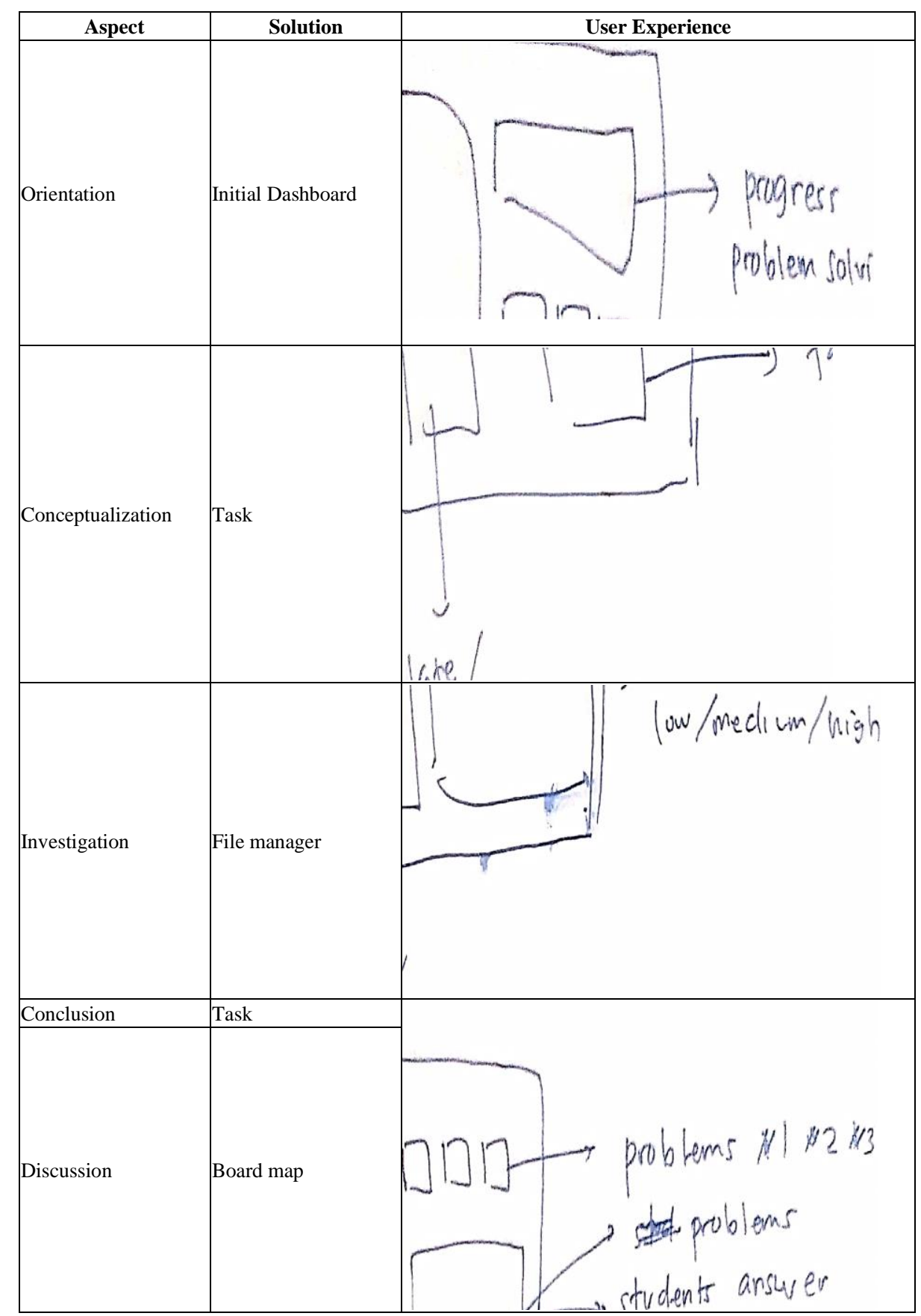




\subsection{Development stage}

IMMI development included two stages, namely making user interface design and making programming languages. Initially, researchers created a design on Adobe XD to determine the user interface results from IMMI, which consists of several layers with three main layers, namely the signup/sign in, dashboard, and task, Figure 2a. Furthermore, writing a programming language is written in Visual Code Studio using the Flutter language as a reference for IMMI through the website and/or smartphone application shown in Figure $2 b$.

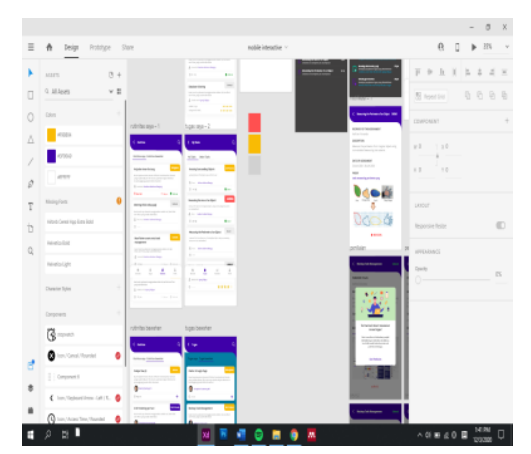

(a) The process of creating a user interface design

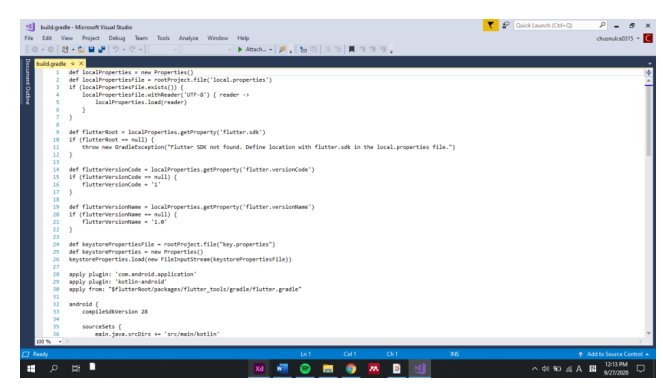

(b) Flutter language programming process in Visual Code Studio

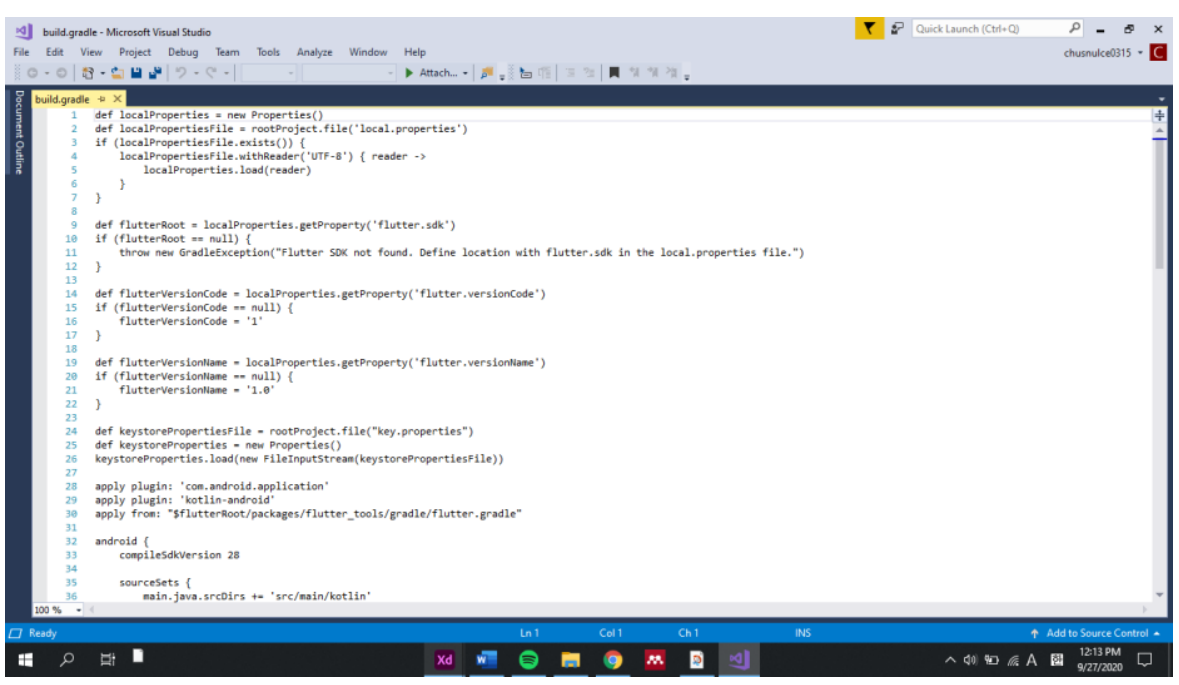

Fig. 2. 


\subsection{Wrapping stage}

At the wrapping stage, IMMI had gone through the development stage. Therefore, the prototypes that had been made was used to be validated by experts. Prototype 1 consists of a multimedia homepage, inquiry assignment format, and a forum for discussion in one class or private chat.

Homepage: The start page consists of the main menu to easily access other features. Learning statistics is useful for measuring the value or frequency of time using IMMI for learning, column classmates. There is a feature of progress in-class assignments and measurement results of student abilities. This feature on the homepage is expected to enable students to find initial problems and serve as a forum for discussion.

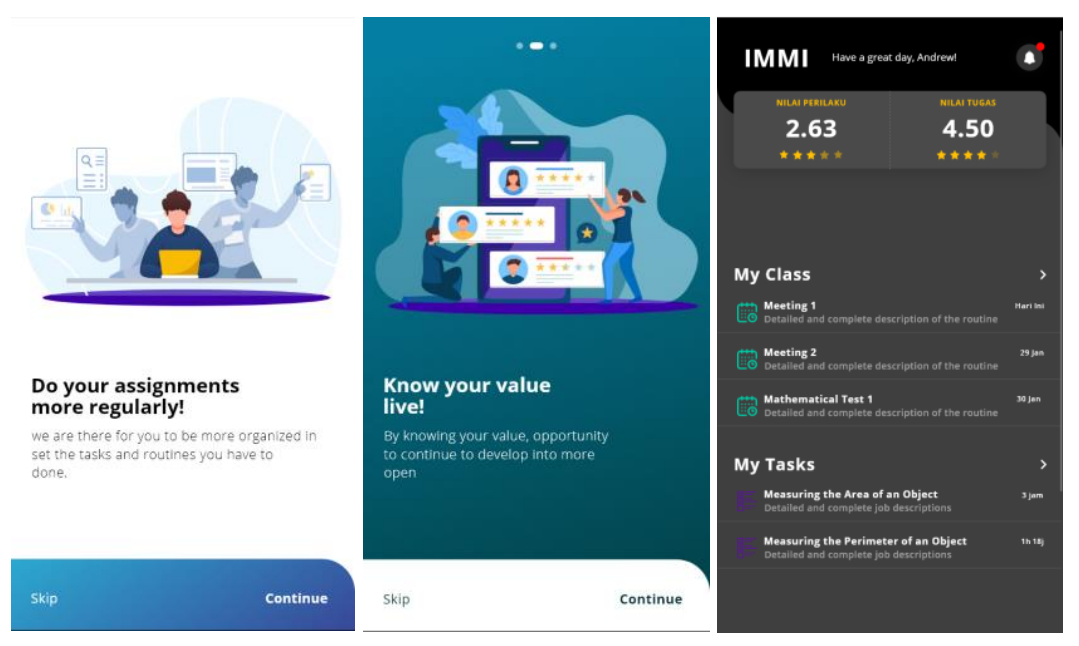

Fig. 3. Interface Homepage or Dashboard

Inquiry assignment: This assignment was set with a calendar by the lecturer in the form of a reminder. The file manager feature helps students find out how deep the inquiry process was by providing high, low, medium, and not satisfied files. The giving of the information serves to test the tentative answers to dig again to get even better results. 


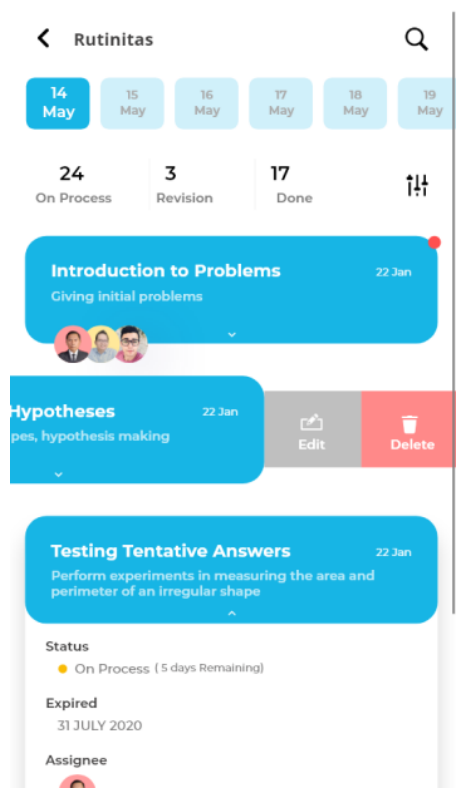

Fig. 4. Interface Task Calendar and File Manager Assignment Features

Figure 4 shows the assignment activities in IMMI involving aspects of inquiry that must be completed by students. In this feature interface, the learning consists of five inquiry activities described in more detail in Table 2.

Table 2. Student inquiry activities in IMMI

\begin{tabular}{|l|l|}
\hline \multicolumn{1}{|c|}{ Aspect } & \multicolumn{1}{c|}{ Students Activities } \\
\hline Orientation & Students showed or photographed plain objects around \\
\hline Conceptualization & $\begin{array}{l}\text { Students wrote an initial hypothesis about the definition of the area and circumference } \\
\text { of a flat shape }\end{array}$ \\
\hline Investigation & $\begin{array}{l}\text { Students measured the area and circumference of irregular plain objects; then, the } \\
\text { measurement results were photographed and uploaded to mobile interactive. The lec- } \\
\text { turer corrects student assignments to give a sign of revision or not. If the lecturer pro- } \\
\text { vides a revised statement, students could re-upload the answer }\end{array}$ \\
\hline Conclusion & $\begin{array}{l}\text { Students write conclusions from the understanding of the area and circumference of a } \\
\text { flat shape }\end{array}$ \\
\hline Discussion & Students discuss concepts \\
\hline
\end{tabular}

There is also a forum for discussion between students or students and teachers in one class. This forum for discussion is useful for bringing up the values of society 5.0 at IMMI. In addition to the relationship between students and technology, the interaction between students and their environment through technology is also needed. Snippets from this discussion forum are shown in Figure 5. 

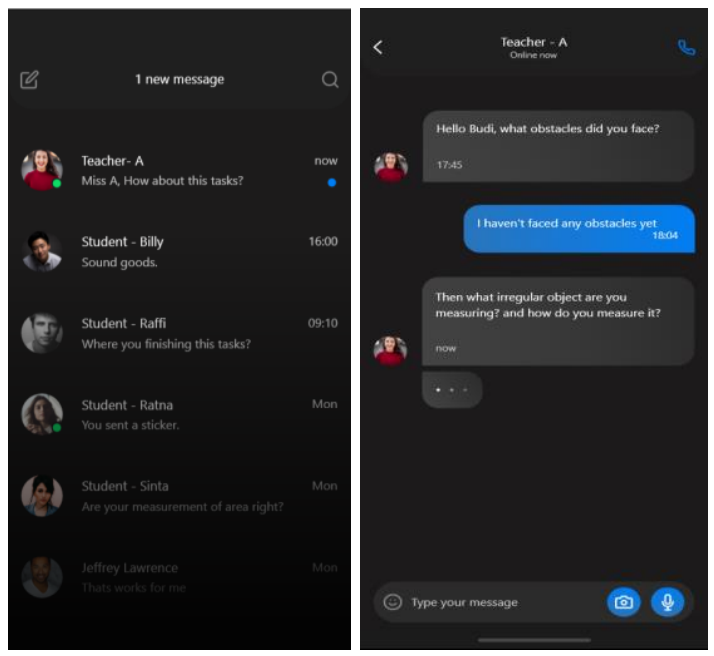

Fig. 5. Interface Features for Discussion

\subsection{Review and adjust stage}

The validation of experts from a value range of 1 to 5 on relevance, effectiveness, and feasibility is shown in Figure 6.

\section{Results of IMMI Validation}

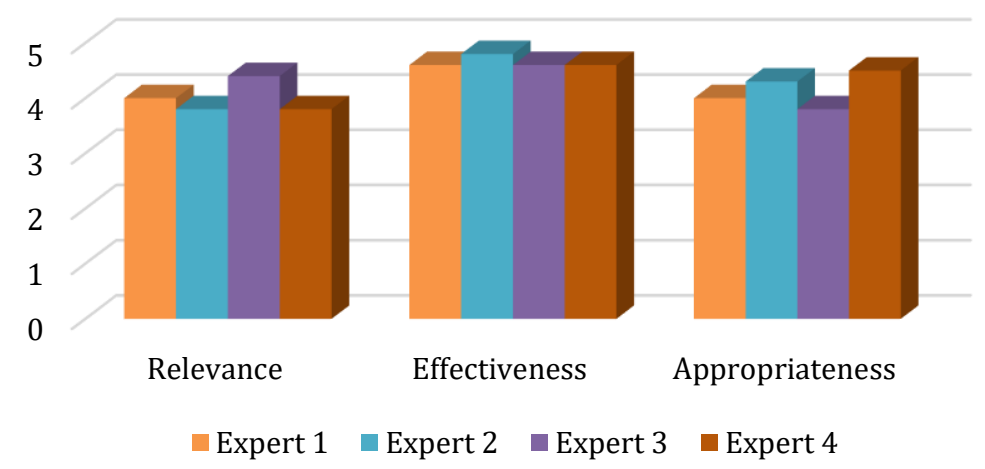

Fig. 6. Result of Expert Validation

Figure 6 explained that the highest value of validity lies in the aspect of effectiveness, with an average value of 4.66. The feasibility aspect shows an average value of 4.3 and the relevance aspect with an average value of 4 . From the validation results, several validators gave suggestions to improve IMMI (see table 3), which then carried out IMMI improvements (see figure 7 ). 
Table 3. IMMI Revision Result

\begin{tabular}{|c|l|}
\hline Recommendation & \multicolumn{1}{c|}{ Revision } \\
\hline The assignment has not been described scientifically & (See Figure 7) \\
\hline
\end{tabular}

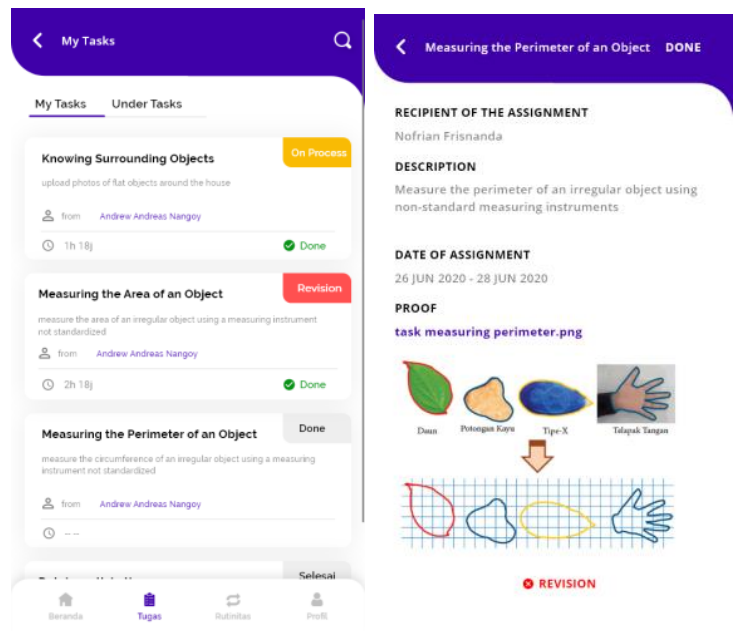

Fig. 7. Inquiry assignment in IMMI

Figure 7 shows the results of IMMI improvements from the validator's suggestions. The improvements made lie in the sharpness and accuracy of involving aspects of the inquiry in IMMI. Referring to Polya, several assignments are adjusted to the problemsolving indicators, which are depicted in Figure 8.

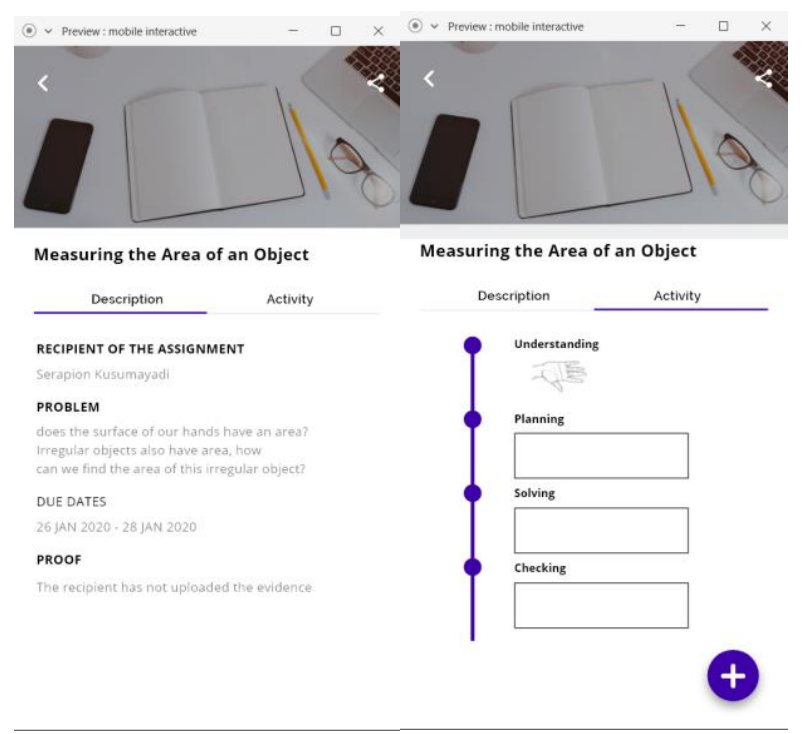

Fig. 8. Problem-solving in IMMI 


\subsection{Closure stage}

After the IMMI improvements, the closure stage measures the effect of IMMI on students' problem-solving abilities. If the problem-solving ability has a significant effect, the IMMI development process is said to be complete. The relationship between the IMMI variable and the student's problem-solving ability is known using a simple linear regression analysis test shown in Table 4.

Table 4. The results of simple linear regression analysis

\begin{tabular}{|l|c|c|c|c|c|}
\hline \multirow{2}{*}{ Model } & \multicolumn{2}{|c|}{ Unstandardized Coefficients } & Standardized Coefficients & \multirow{2}{*}{ t } & \multirow{2}{*}{ Sig. } \\
\cline { 2 - 6 } & $\boldsymbol{B}$ & Std Error & Beta & 6.786 & 0.000 \\
\hline (Constant) & 3.212 & 1.221 & & -2.012 & 0.001 \\
\hline $\begin{array}{l}\text { Understanding } \\
\text { Problem }\end{array}$ & -0.012 & 0.217 & -0.454 & -2.431 & 0.000 \\
\hline Planning solutions & 0.333 & 0.436 & -0.566 & -2.126 & 0.000 \\
\hline Implementing solution plan & -0.677 & 0.122 & -0.199 & -1.999 & 0.001 \\
\hline Re-checking solutions & 0.096 & 0.055 & 0.002 & \multicolumn{2}{|c}{} \\
\hline
\end{tabular}

Table 4 shows the simple linear regression analysis results between the use of IMMI on students' problem-solving abilities. The results show that the $t$-value of the indicator of the ability to understand the problem is -2.012 , while the $t$-value of the planning solution's indicator is -2.431 . The indicator of implementing solution plans shows the $\mathrm{t}$-count value of -2.126 , and the indicator re-checking solution has a t-count value of 1.999. The $t$-count value of the four indicators shows the $t$-count value is less than 1.97993. Thus, it can be interpreted that the t-count is less than the t-table. In conclusion, $\mathrm{H} 0$ is rejected and shows that IMMI influences students' problem-solving abilities. In particular, the plan and implementation indicators show a significant value so that the two indicators show that students' problem-solving skills increase when planning and implementing through IMMI.

\subsection{Discussion}

This study presents the results of the development of IMMI at the tertiary higher education. The main finding is that the development of IMMI affects students' mathematical problem-solving abilities. The improvement of students' mathematical problem-solving abilities occurs in planning and executing the plan. This finding is similar to previous research results that problem-based Interactive Mobile will improve students' mathematical problem-solving skills regularly [26],[27]. The results of other studies suggest that the improvement in planning and planning implementation is due to the habituation of inquiry aspects in learning [28]. IMMI supports the practice of teaching mathematics, which is scientific. This teaching is based not only on knowledge transfer but also on inquiry and student communication to construct knowledge and information [29]. Judging from this construction, student interaction and technology in IMMI can help simplify solving a problem [30].

The research has also shown improvements in the inquiry process and provides students with activities to select, control variables, plan operations, and interpret evidence 
in IMMI. This is the same as previous research, which shows that students become more responsive to this inquiry learning situation. Structured activities allow for individual and collaborative work and concrete experiences of learning materials powered by mobile technology that highlight and capture essential features [31], [32].

IMMI emphasizes discursive processes in which mathematical concepts and scientific research processes take place through participation in applied research and social interactions as crucial as mathematical knowledge construction activities both individually and in groups [33]. Interaction with peers while conducting scientific research provides the development of learning and scientific understanding [34]. Scientific reasoning can be achieved by exposing students to abnormal data or contradictory information in science or other academic fields. This allows students to build scientific knowledge in scientific inquiry. Critically, the relationship between theory and evidence in the problem-solving reasoning process can also be evaluated [35]. From this perspective, lecturers play a vital role in developing students' scientific reasoning skills [36]. Lecturers provide IMMI to develop an environment and learning process that aims to shape science process skills to increase students' problem-solving abilities. Thus, the results of IMMI as a result of development in this research can be an initial study for experts and practitioners in educational technology interested in preparing for a media presence in the Era of Society 5.0. In particular, it will be essential in developing Interactive Mobile to improve students' Mathematics problem-solving abilities at the higher education higher education.

\section{Conclusion}

Based on the results and discussion of research, the researcher concluded that the development of IMMI, an Interactive Mobile involving aspects of inquiry in mathematics courses, is valid and able to improve students' problem-solving abilities. In particular, this increase is significant in planning and implementing student plans for a problem. Also, the significance of the increase in problem-solving abilities is due to the training of inquiry aspects during the use of IMMI.

\section{$5 \quad$ References}

[1] M. E. Gladden, "Who Will Be the Members of Society 5.0? Towards an Anthropology of Technologically Post humanized Future Societies,” Soc. Sci., vol. 8, no. 5, p. 148, May 2019. https://doi.org/10.3390/socsci8050148

[2] X. Wang, L. Li, Y. Yuan, P. Ye, and F.-Y. Wang, "ACP-based social computing and parallel intelligence: Societies 5.0 and beyond," CAAI Trans. Intel. Technol., vol. 1, no. 4, pp. 377393, 2016. https://doi.org/10.1016/j.trit.2016.11.005

[3] J. Nieuważny, F. Masui, M. Ptaszynski, R. Rzepka, and K. Nowakowski, "How religion and morality correlate in age of society 5.0: Statistical analysis of emotional and moral associations with Buddhist religious terms appearing on Japanese blogs," Cogn. Syst. Res., vol. 59, pp. 329-344, Jan. 2020. https://doi.org/10.1016/j.cogsys.2019.09.026 
[4] K. A. Demir, G. Döven, and B. Sezen, "Industry 5.0 and Human-Robot Co-working," Procedia Comput. Sci., vol. 158, pp. 688-695, 2019. https://doi.org/10.1016/j.procs. 2019.09.104

[5] R. C. Mat, M. Kazunori, and A. A. Rahman, "The Development of Mobile Japanese Halal Gamification (MJHG),” Int. J. Interact. Mob. Technol., vol. 14, no. 17, p. 113, 2020. https://doi.org/10.3991/ijim.v14i17.16653

[6] V. Sima, I. G. Gheorghe, J. Subić, and D. Nancu, "Influences of the Industry 4.0 Revolution on the Human Capital Development and Consumer Behavior: A Systematic Review," Sustainability, vol. 12, no. 10, p. 4035, May 2020. https://doi.org/10.3390/su12104035

[7] W. Herry Setyawan et al., "The effect of an android-based application on T-Mobile learning model to improve students' listening competence," in Journal of Physics: Conference Series, 2019, vol. 1175, no. 1. https://doi.org/10.1088/1742-6596/1175/1/012217

[8] L. Barkhuus and V. E. Polichar, "Empowerment through seamfulness: smart phones in everyday life," Pers. Ubiquitous Comput., vol. 15, no. 6, pp. 629-639, Aug. 2011. https://doi.org/10.1007/s00779-010-0342-4

[9] V. Baric, M. Andreassen, A. Öhman, and H. Hemmingsson, "Using an interactive digital calendar with mobile phone reminders by senior people - a focus group study," BMC Geriatr., vol. 19, no. 1, p. 116, Dec. 2019. https://doi.org/10.1186/s12877-019-1128-9

[10] M. F. Amir, N. Fediyanto, H. E. Rudyanto, D. S. N. Afifah, and H. S. Tortop, "Elementary students' perceptions of 3Dmetric: A cross-sectional study," Heliyon, vol. 6, no. 6, pp. 1-8, 2020. https://doi.org/10.1016/j.heliyon.2020.e04052

[11] M. Pedaste et al., "Phases of inquiry-based learning: Definitions and the inquiry cycle," Educational Research Review, vol. 14. 2015.

[12] D. D. Minner, A. J. Levy, and J. Century, "Inquiry-based science instruction-what is it and does it matter? Results from a research synthesis year 1984 to 2002," J. Res. Sci. Teach., vol. 47, no. 4, pp. 474-496, Apr. 2010. https://doi.org/10.1002/tea.20347

[13] L. Darling-Hammond, L. Flook, C. Cook-Harvey, B. Barron, and D. Osher, "Implications for educational practice of the science of learning and development," Appl. Dev. Sci., vol. 24, no. 2, pp. 97-140, Apr. 2020. https://doi.org/10.1080/10888691.2018. $\underline{1537791}$

[14] C. J. Chang et al., "The impact of light-weight inquiry with computer simulations on science learning in classrooms," Comput. Educ., vol. 146, p. 103770, 2020.

[15] M. Ekici and M. Erdem, "Developing Science Process Skills through Mobile Scientific Inquiry,” Think. Ski. Creat., vol. 36, no. December 2019, p. 100658, 2020. https://doi.org/10. 1016/j.tsc.2020.100658

[16] P. Phonapichat, S. Wongwanich, and S. Sujiva, "An Analysis of Elementary School Students' Difficulties in Mathematical Problem Solving," Procedia - Soc. Behav. Sci., vol. 116, pp. 3169-3174, Feb. 2014. https://doi.org/10.1016/j.sbspro.2014.01.728

[17] T. Tambychik, T. S. M. Meerah, and Z. Aziz, "Mathematics Skills Difficulties: A Mixture of Intricacies," Procedia - Soc. Behav. Sci., vol. 7, pp. 171-180, 2010. https://doi.org/10. 1016/j.sbspro.2010.10.025

[18] S. Avcu and R. Avcu, "Pre-service elementary mathematics teacher's use of strategies in mathematical problem solving," Procedia - Soc. Behav. Sci., vol. 9, pp. 1282-1286, 2010. https://doi.org/10.1016/j.sbspro.2010.12.321

[19] Z. B. Özdoğan, E. Seyitoğlu, and B. Güven, "The change over the years of problem-solving skills of pre-service elementary mathematics teachers," Procedia - Soc. Behav. Sci., vol. 15, pp. 2278-2283, 2011. https://doi.org/10.1016/j.sbspro.2011.04.093 
[20] F. Almudarra and B. Qureshi, "Issues in adopting agile development principles for mobile cloud computing applications," Procedia Comput. Sci., vol. 52, no. 1, pp. 1133-1140, 2015. https://doi.org/10.1016/j.procs.2015.05.131

[21] A. Rasnacis and S. Berzisa, "Method for Adaptation and Implementation of Agile Project Management Methodology," Procedia Comput. Sci., vol. 104, no. December 2016, pp. 4350, 2016. https://doi.org/10.1016/j.procs.2017.01.055

[22] Martínez-Mesa, D. A. González-Chica, R. P. Duquia, R. R. Bonamigo, and J. L. Bastos, "Sampling: how to select participants in my research study?" An. Bras. Dermatol., vol. 91, no. 3, pp. 326-330, Jun. 2016. https://doi.org/10.1590/abd1806-4841.20165254

[23] G. Polya, How to Solve It. Princeton, New jersey: Princeton University Press, 1973.

[24] J. W. Creswell, Educational research: Planning, conducting, and evaluating quantitative and qualitative research, vol. 4. 2012.

[25] H. Lei, F. Ganjeizadeh, P. K. Jayachandran, and P. Ozcan, "A statistical analysis of the effects of Scrum and Kanban on software development projects," Robot. Comput. Integr. Manuf., vol. 43, pp. 59-67, 2017. https://doi.org/10.1016/j.rcim.2015.12.001

[26] M. F. Amir, F. N. Hasanah, and H. Musthofa, "Interactive Multimedia Based Mathematics Problem Solving to Develop Students' Reasoning,” Int. J. Eng. Technol., vol. 7, no. 2.14, pp. 272-276, 2018. https://doi.org/10.31219/osf.io/qx63e

[27] M. F. Amir, N. Ariyanti, N. Anwar, E. Valentino, and D. S. N. Afifah, "Augmented Reality Mobile Learning System: Study to Improve PSTs' Understanding of Mathematical Development," Int. J. Interact. Mob. Technol., vol. 14, no. 9, pp. 239-247, 2020. https://doi.org/10.3991/ijim.v14i09.12909

[28] K. Maßß and M. Doorman, "A model for a widespread implementation of inquiry-based learning," ZDM, vol. 45, no. 6, pp. 887-899, Nov. 2013. https://doi.org/10.1007/ $\underline{\text { s11858-013-0505-7 }}$

[29] M. J. Ford and E. A. Forman, "Chapter 1: Redefining disciplinary learning in classroom contexts," in review of research in education, New York: Springer, 2006, pp. 1-32. https://doi.org/10.3102/0091732x030001001

[30] Y.-T. Sung, K.-E. Chang, and T.-C. Liu, "The effects of integrating mobile devices with teaching and learning on students' learning performance: A meta-analysis and research synthesis," Comput. Educ., vol. 94, pp. 252-275, Mar. 2016. https://doi.org/10.1016/j. compedu.2015.11.008

[31] E. Y.-K. Loong, C. Vale, S. Herbert, L. A. Bragg, and W. Widjaja, "Tracking Change in Primary Teachers' Understanding of Mathematical Reasoning through Demonstration Lessons," Math. Teach. Educ. Dev., vol. 19, no. 1, pp. 5-19, 2017.

[32] H. E. Rudyanto, A. Ghufron, and Hartono, "Use of integrated mobile application with realistic mathematics education: A study to develop elementary students' creative thinking ability,” Int. J. Interact. Mob. Technol., vol. 13, no. 10, pp. 19-27, 2019. https://doi.org/10. $\underline{\text { 3991/ijim.v13i10.11598 }}$

[33] M. J. Mohr-Schroeder, M. Cavalcanti, and K. Blyman, "Stem Education: Understanding the Changing Landscape," in A Practice-based Model of STEM Teaching, Rotterdam: SensePublishers, 2015, pp. 3-14. https://doi.org/10.1007/978-94-6300-019-2_1

[34] N. Mercer, L. Dawes, R. Wegerif, and C. Sams, "Reasoning as a scientist: Ways of helping children to use language to learn science," Br. Educ. Res. J., vol. 30, no. 3, pp. 359-377, 2004. https://doi.org/10.1080/01411920410001689689

[35] F.-Y. Yang and C. C. Tsai, "An epistemic framework for scientific reasoning in informal contexts," in Personal epistemology in the classroom, Cambridge: Cambridge University Press, 2010, pp. 124-162. https://doi.org/10.1017/cbo9780511691904.005 
[36] C. Chin and J. Osborne, "Students' questions: a potential resource for teaching and learning science,” Stud. Sci. Educ., vol. 44, no. 1, pp. 1-39, Mar. 2008.

\section{Authors}

Moch. Bahak Udin By Arifin is a lecturer at the Madrasah Ibtidaiyah Teacher Education Department, Universitas Muhammadiyah Sidoarjo from 2014 until now. He is in the field of Islamic primary school curriculum development education. The research topic that is often used is the development of a curriculum on learning media innovation in Islamic elementary schools. Email: bahak.udin@umsida.ac.id

Makherus Sholeh is a Lecturer in the Madrasah Ibtidaiyah Teacher Education Department at the Universitas Islam Negeri Antasari Banjarmasin from 2015 until now. $\mathrm{He}$ is a candidate for the Doctor of Islamic Education Management for Elementary Schools. Research topics that are frequently used are educational management and all primary school education topics.

Abdul Hafiz started his career as a lecturer in 2015, in the Madrasah Ibtidaiyah Teacher Education Department at Universitas Islam Kalimantan Muhammad Arsyad Al Banjari Banjarmasin. He has also served as head of the study program and then serves as Deputy Dean for Student and Alumni Affairs at the Faculty of Islamic Studies. Research topics that are often used are about curriculum development, Syllabus and Lesson Plan, and learning media in primary schools.

Ririn Dwi Agustin is a lecturer at the Mathematics Education Study Program, IKIP Budi Utomo, Malang, Indonesia from 2014 until now. Algebra Expertise. Research topics that are often used are the development of ethnomathematics and mathematics encyclopedias on technology-based learning media innovations.

Mahardika Darmawan Kusuma Wardana is a lecturer at the Elementary School Teacher Education Department, Universitas Muhammadiyah Sidoarjo from 2015 until now. He is in the field of elementary school education. The research topic that is often used such as Mathematics Elementary Education, Language primary education and all topic about elementary education.

Article submitted 2020-11-27. Resubmitted 2020-12-18. Final acceptance 2020-12-19. Final version published as submitted by the authors. 